\title{
APLIKASI SISTEM INFORMASI GEOGRAFIS PADA SALURAN DISTRIBUSI LISTRIK PRIMER DI WILAYAH KOTA PALU
}

\author{
Deny Wiria Nugraha \\ Jurusan Teknik Elektro, Fakultas Teknik, Universitas Tadulako \\ Alamat Instansi: Jl. Soekarno Hatta Km. 9, Kampus Bumi Tadulako Tondo Palu, \\ Sulawesi Tengah \\ email : deny_wiria_nugraha@yahoo.co.id
}

\begin{abstract}
This study uses ArcView GIS 3.3 program which comes with a programming script Avenue for implementing a geographic information system primary electrical distribution channels in the city of Palu using digital maps and relationships between database tables. Geographic information system designed and fabricated in this study proved capable of displaying all the information on the primary electrical distribution channels in which the data taken from the PT. PLN (Persero) rayon branch of Palu city. The information can be displayed include information distribution poles, distribution substations, LBS/ABS, cable/conductor is used, and others. Relationships between tables in the database proved to be able to create a good data base, the efficiency of data storage, high data integrity, the structure of each table is more efficient and systematic, processing speed, and ease of database operations.
\end{abstract}

\section{Keywords : Geographic Information Systems, Digital Map, Database, Primary Electrical}

Penelitian ini menggunakan program ArcView GIS 3.3 yang dilengkapi dengan pemrograman script Avenue untuk mengimplementasikan sistem informasi geografis saluran distribusi listrik primer di wilayah kota Palu dengan menggunakan peta digital dan relasi antar tabel basis data. Sistem informasi geografis yang dirancang dan dibuat pada penelitian ini terbukti mampu menampilkan keseluruhan informasi yang ada pada saluran distribusi listrik primer dimana datanya diambil dari PT. PLN (Persero) cabang Palu rayon kota. Informasi yang dapat ditampilkan antara lain informasi tiang-tiang distribusi, gardu distribusi, LBS/ABS, kabel/penghantar yang digunakan, dan lain-lain. Relasi antar tabel dalam basis data terbukti dapat menciptakan sebuah basis data yang baik, efisiensi tempat penyimpanan data, integritas data yang tinggi, struktur masing-masing tabel yang lebih efisien dan sistematis, kecepatan pemrosesan, dan kemudahan dalam operasi basis data.

\section{Kata Kunci : Sistem Informasi Geografis, Peta Digital, Basis Data}

\section{PENDAHULUAN}

Teknologi di bidang teknik elektro khususnya teknologi informasi dewasa ini dapat diterapkan pada segala bidang kehidupan. Dalam perkembangan teknologi yang pesat ini, teknologi informasi dapat dimanfaatkan sebagai sarana informasi untuk saluran distribusi listrik primer dalam bentuk sebuah sistem informasi geografis sehingga memudahkan pengguna sistem tersebut untuk mengetahui kondisi dari saluran distribusi listrik.

Sampai saat ini untuk mendapatkan informasi mengenai saluran distribusi listrik primer masih dilakukan secara konvensional yaitu dengan hanya menampilkan informasi menggunakan program aplikasi Microsoft Office Word dan Excel. Sehingga perusahaan dalam hal ini PT. PLN (Persero) cabang Palu rayon kota memasukkan data saluran distribusi listrik primer secara manual misalnya data tiang, data gardu, data kabel (penghantar), data pemakai (beban), data LBS (Load Breaker Switch) atau ABS (Air Breaker Switch), data peta distribusi, dan sebagainya tanpa menggunakan peta digital dan media penyimpanan data (basis data) yang saling berhubungan.

Cara kovensional tersebut di atas memiliki banyak kerugian yaitu tidak dapat menghasilkan informasi yang akurat, masih menggunakan peta analog yang tidak sesuai dengan kondisi geografis, seringkalinya terjadi kesalahan pembacaan data, dan sangat kesulitan dalam melakukan perubahan data. Untuk menghindari hal tersebut, maka diperlukan suatu sistem informasi geografis saluran distribusi listrik 
primer yang dapat menampilkan keseluruhan informasi dengan menggunakan peta digital yang sesuai kondisi geografis wilayah kota Palu.

Bertitik tolak dari permasalahan tersebut di atas dan seiring dengan pesatnya perkembangan teknologi khususnya dalam hal bidang teknologi informasi yang terdiri dari perkembangan perangkat lunak dan perangkat keras, maka dalam penelitian ini akan menghasilkan suatu sistem informasi geografis saluran distribusi listrik primer di wilayah kota Palu dengan menggunakan peta digital dan relasi antar tabel basis data.

Penelitian ini memiliki tujuan adalah untuk membuktikan bahwa sistem informasi geografis yang dirancang dan dibuat mampu menampilkan keseluruhan informasi yang ada pada saluran distribusi listrik dimana datanya diambil dari PT. PLN (Persero) cabang Palu rayon kota. Penelitian ini diharapkan dapat bermanfaat dengan memberikan kontribusi terhadap dunia akademisi yaitu untuk menambah wawasan dan ilmu pengetahuan tentang sistem informasi geografis, peta digital, basis data, relasi antar tabel basis data, program ArcView GIS 3.3, dan saluran distribusi listrik primer. Penelitian ini diharapkan juga dapat memberikan masukan kepada praktisi dalam merancang suatu sistem informasi geografis saluran distribusi listrik primer dengan menggunakan peta digital dan relasi antar tabel basis data.

\section{Rumusan Masalah}

Permasalahan yang dihadapi dalam penelitian ini adalah pemanfaatan sistem informasi geografis yang dapat menampilkan keseluruhan informasi yang ada pada saluran distribusi listrik primer dimana datanya diambil dari PT. PLN (Persero) cabang Palu rayon kota.

Perumusan masalah dalam penelitian ini berkaitan dengan bagaimana cara mengimplementasikan sistem informasi geografis saluran distribusi listrik primer di wilayah kota Palu dengan menggunakan peta digital dan relasi antar tabel basis data.

\section{TINJAUAN PUSTAKA}

\subsection{Sistem Informasi}

Definisi dari sistem informasi adalah sebagai kumpulan elemen yang saling berhubungan satu sama lain yang membentuk satu kesatuan untuk mengintegrasikan data, memproses dan menyimpan serta mendistribusikan informasi (Oetomo, 2006:11).

Menurut Alter (dalam Kadir, 2003:11) sistem informasi adalah kombinasi antara prosedur kerja, informasi, orang, dan teknologi informasi yang diorganisasikan untuk mencapai tujuan dalam organisasi.

Sedangkan Kristanto (2008:12) berpendapat bahwa sistem informasi merupakan kumpulan dari perangkat keras dan perangkat lunak komputer serta perangkat manusia yang akan mengolah data menggunakan perangkat keras dan perangkat lunak tersebut.

Kemampuan suatu sistem informasi adalah melaksanakan komputasi numerik, bervolume besar, dengan kecepatan tinggi; menyediakan komunikasi dalam organisasi atau antar-organsiasi yang murah, akurat, dan cepat; menyimpan informasi dalam jumlah yang sangat besar dalam ruang yang kecil tetapi mudah diakses; memungkinkan pengaksesan informasi yang sangat banyak di seluruh dunia dengan cepat dan murah; meningkatkan efektivitas dan efisiensi orang-orang yang bekerja dalam kelompok dalam suatu tempat atau pada beberapa lokasi; menyajikan informasi dengan jelas yang menggugah pikiran manusia; mengotomasikan proses-proses bisnis yang semi-otomatis dan tugas-tugas yang dikerjakan secara manual; mempercepat pengetikan dan penyuntingan; dan melaksanakan hal-hal di atas jauh lebih murah daripada kalau dikerjakan secara manual.

\subsection{Sistem Informasi Geografis}

Sistem Informasi Geografis atau disingkat SIG merupakan suatu sistem berbasis komputer yang digunakan untuk mengumpulkan, menyimpan, mengatur, mentransformasi, memanipulasi, dan menganalisis data-data geografis (Yousman, 2004:1). Data geografis yang dimaksud disini adalah data spasial yang ciri-cirinya adalah:

1. Memiliki geometric properties seperti koordinat dan lokasi.

2. Terkait dengan aspek ruang seperti persil, kota, kawasan pembangunan.

3. Berhubungan dengan semua fenomena yang terdapat di bumi, misalnya data, kejadian, gejala atau objek.

4. Dipakai untuk maksud-maksud tertentu, misalnya analisis, pemantauan ataupun pengelolaan. 
Kebanyakan SIG menggunakan konsep "lapis" (layer). Setiap lapisan mewakili satu fitur geografi dalam area yang sama dan selanjutnya semua lapisan bisa saling ditumpuk untuk mendapatkan informasi yang lengkap. Setiap lapisan dapat dibayangkan seperti plastik transparan yang mengandung hanya gambar tertentu. Pemakai bisa memilih transparantransparan yang dikehendaki dan kemudian saling ditumpangkan sehingga akan diperoleh gambar yang merupakan gabungan dari sejumlah transparan (Kadir, 2003:134).

Salah satu perangkat lunak Sistem Informasi Geografis adalah ArcView. Dengan ArcView, pengguna dapat memiliki kemampuan-kemampuan untuk melakukan visualisasi, meng-explore, menjawab query (baik basis data spasial maupun non spasial), menganalisis data secara geografis, dan sebagainya (Prahasta, 2009:1). Dan, untuk mengoptimalkan (mengotomasikan, meng-customize-kan), mensistematikkan, me-reuse-kan, dan sebagainya) aplikasi-aplikasi SIG yang dikembangkan dengan menggunakan ArcView mengintegrasikan Avenue yang sangat mudah untuk digunakan di dalamnya. Avenue merupakan bahasa pemrograman yang hadir bersama dengan (terintegrasi dengan paket standar) ArcView (Prahasta, 2004:1).

\subsection{Basis Data (Database)}

Basis Data terdiri atas 2 kata, yaitu Basis dan Data. Basis kurang lebih dapat diartikan sebagai markas atau gudang, tempat bersarang/berkumpul. Sedangkan Data adalah representasi fakta dunia nyata yang mewakili suatu objek seperti manusia (pegawai, siswa, pembeli, pelanggan), barang, hewan, peristiwa, konsep, keadaan, dan sebagainya, yang direkam dalam bentuk angka, huruf, simbol, teks, gambar, bunyi, atau kombinasinya (Fathansyah, 1999:2).

Basis data (database) adalah suatu pengorganisasian sekumpulan data yang saling terkait sehingga memudahkan aktivitas untuk memperoleh informasi. Basis data dimaksudkan untuk mengatasi problem sistem yang memakai pendekatan berbasis berkas (Kadir, 2003:254).

Untuk mengelola basis data diperlukan perangkat lunak yang disebut DBMS (Database Management System). Manajemen Sistem Basis Data (Database Management System) adalah perangkat lunak yang didesain untuk membantu dalam hal pemeliharaan dan utilitas kumpulan data dalam jumlah besar. DBMS dapat menjadi alternatif penggunaan secara khusus untuk aplikasi, semisal penyimpanan data dalam field dan menulis kode aplikasi yang spesifik untuk pengaturannya (Kristanto, 2008:79).

Keuntungan penggunaan basis data, yaitu:

1. Kebebasan data dan akses yang efisien.

2. Mereduksi waktu pengembangan aplikasi.

3. Integritas dan keamanan data.

4. Administrasi keseragaman data.

5. Akses bersamaan dan perbaikan dari terjadinya crashes (tabrakan dari proses serentak).

\subsection{Peta Digital}

Peta digital adalah representasi fenomena geografik yang disimpan untuk ditampilkan dan dianalisis oleh komputer digital (Nuryadin, 2005:19). Setiap objek pada peta digital disimpan sebagai sebuah atau sekumpulan koordinat. Sebagai contoh, objek berupa lokasi sebuah titik akan disimpan sebagai sebuah koordinat, sedangkan objek berupa wilayah akan disimpan sebagai sekumpulan koordinat.

Beberapa kelebihan penggunaan peta digital dibandingkan dengan peta analog (yang disimpan dalam bentuk kertas atau media cetakan lain), antara lain dalam hal (Nuryadin, 2005:19):

1. Peta digital kualitasnya tetap. Tidak seperti kertas yang dapat terlipat, memuai atau sobek ketika disimpan, peta digital dapat dikembalikan ke bentuk asalnya kapanpun tanpa ada penurunan kualitas.

2. Peta digital mudah disimpan dan dipindahkan dari satu media penyimpanan yang satu ke media penyimpanan yang lain. Peta analog yang disimpan dalam bentuk gulungan-gulungan kertas misalnya, memerlukan ruangan yang lebih besar dibanding dengan jika peta tersebut disimpan sebagai peta digital dalam sebuah hard disk, CD-ROM atau DVD-ROM.

3. Peta digital lebih mudah diperbarui. Penyuntingan untuk keperluan pemutakhiran data atau perubahan sistem koordinat misalnya, dapat lebih mudah dilakukan menggunakan perangkat lunak tertentu. 


\subsection{Saluran Distribusi Listrik}

Sistem distribusi merupakan bagian dari sistem tenaga listrik. Sistem distribusi ini berguna untuk menyalurkan tenaga listrik dari sumber daya listrik besar (bulk power source) sampai ke konsumen (Hage, 2008:1).

Jadi fungsi distribusi listrik adalah:

1. Pembagian atau penyaluran tenaga listrik ke beberapa tempat (pelanggan).

2. Merupakan sub sistem tenaga listrik yang langsung berhubungan dengan pelanggan, karena catu daya pada pusat-pusat beban (pelanggan) dilayani langsung melalui saluran distribusi.

Sistem distribusi merupakan bagian yang penting dalam sistem tenaga listrik secara keseluruhan. Konfigurasi sistem tenaga listrik dapat dilihat pada gambar 1 (Kadir, 2006:5).

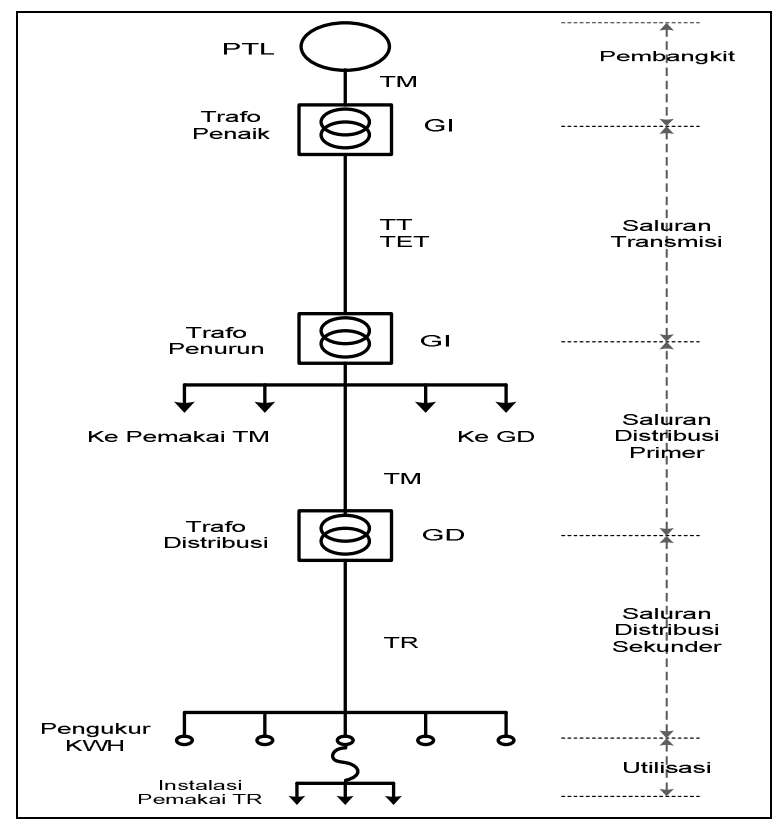

Gambar 1. Konfigurasi sistem tenaga listrik

Berdasarkan gambar 1 di atas, maka dapat dikelompokkan dalam beberapa pembagian sebagai berikut:

1. Daerah I : bagian pembangkitan (generation).

2. Daerah II : bagian penyaluran (transmission) bertegangan tinggi (HV, UHV, dan EHV).

3. Daerah III : bagian distribusi primer bertegangan menengah $(6,12$, atau $20 \mathrm{KV})$.

4. Daerah IV : bagian distribusi sekunder bertegangan rendah.

Menurut nilai tegangannya, saluran tenaga listrik atau saluran distribusi dapat diklasifikasikan sebagai berikut:

1. Saluran distribusi primer, terletak pada sisi primer trafo distribusi, yaitu antara titik sekunder trafo cabang (gardu induk) dengan titik primer trafo distribusi. Saluran ini bertegangan menengah $20 \mathrm{KV}$. Saluran listrik $70 \mathrm{KV}$ atau $150 \mathrm{KV}$, jika langsung melayani pelanggan, bisa disebut saluran distribusi.

Sistem distribusi primer digunakan untuk menyalurkan tenaga listrik dari gardu induk distribusi ke pusat-pusat beban. Sistem ini dapat menggunakan kabel udara maupun kabel tanah sesuai dengan tingkat keandalan yang diinginkan dan kondisi serta situasi lingkungan. Saluran distribusi ini direntangkan sepanjang daerah yang akan disuplai tenaga listrik sampai ke pusat beban.

2. Saluran distribusi sekunder, terletak pada sisi sekunder trafo distribusi, yaitu antara titik sekunder dengan titik cabang menuju beban.

Sistem distribusi sekunder digunakan untuk menyalurkan tenaga listrik dari gardu distribusi ke beban-beban yang ada di konsumen. Pada sistem distribusi sekunder bentuk saluran yang paling banyak digunakan ialah sistem radial. Sistem ini dapat menggunakan kabel yang berisolasi maupun konduktor tanpa isolasi. Sistem ini biasanya disebut sistem 
tegangan rendah yang langsung akan dihubungkan kepada konsumen/pemakai tenaga listrik.

Dalam sistem distribusi, masalah yang utama adalah mengatasi gangguan karena jumlah gangguan dalam sistem distribusi adalah relatif lebih banyak dibandingkan dengan jumlah gangguan pada bagian sistem yang lain. Di samping itu masalah tegangan, bagian-bagian instalasi yang berbeban lebih dan rugi-rugi daya dalam saluran merupakan masalah yang perlu dicatat dan dianalisa secara terus menerus, untuk dijadikan masukan bagi perencanaan pengembangan sistem dan juga untuk melakukan tindakan-tindakan penyempurnaan pemeliharaan dan penyempurnaan operasi sistem distribusi (Marsudi, 2006:14).

\section{METODE PENELITIAN}

\subsection{Jenis Penelitian}

Penelitian ini merupakan penelitian kualitatif dalam bidang teknik elektro dan teknologi informasi khususnya bidang rekayasa perangkat lunak yang sesuai dengan bidang ilmu penulis. Penelitian ini dilakukan dengan cara membangun suatu perangkat lunak (software) berupa sistem informasi geografis saluran distribusi listrik primer dengan menggunakan peta digital dan relasi antar tabel basis data.

\subsection{Lokasi Penelitian}

Lokasi penelitian ini adalah di wilayah kerja PT. PLN (Persero) cabang Palu rayon kota propinsi Sulawesi Tengah. Adapun pertimbangan dalam memilih lokasi penelitian ini karena sampai saat ini untuk mendapatkan informasi mengenai saluran distribusi listrik primer di wilayah kota Palu masih dilakukan secara konvensional yaitu dengan hanya menampilkan informasi menggunakan program aplikasi Microsoft Office Word dan Excel.

\subsection{Bahan Penelitian} berikut:

Data yang merupakan bahan penelitian ini dikumpulkan melalui beberapa metode sebagai

1. Pengumpulan data saluran distribusi listrik primer yang diperoleh dari PT. PLN (Persero) cabang Palu rayon kota.

2. Melakukan pengamatan secara langsung pada saluran distribusi listrik primer yang ada di kota Palu untuk menyesuaikan dengan data yang diterima dari PT. PLN (Persero) cabang Palu rayon kota dengan kondisi yang sebenarnya di lokasi penelitian.

3. Metode wawancara dilakukan dengan bertanya langsung kepada karyawan/pegawai PT. PLN (Persero) cabang Palu rayon kota yang bekerja di bagian distribusi untuk mendapatkan data yang akurat tentang saluran distribusi listrik primer di wilayah kota Palu.

4. Studi literatur, yaitu penelusuran literatur mengenai dasar pengetahuan tentang hal-hal yang berkaitan dengan penelitian ini. Metode ini dilakukan dengan cara mencari buku-buku, artikelartikel, dan jurnal-jurnal ilmiah mengenai sistem informasi geografis, peta digital, basis data, relasi antar tabel basis data, program ArcView, dan saluran distribusi listrik primer.

5. Bahan pendukung penelitian lainnya berupa data denah/peta kota Palu dan sekitarnya.

\subsection{Jenis dan Sumber Data}

Jenis data yang digunakan dalam penelitian ini secara umum dapat dibagi ke dalam dua bagian, yaitu:

1. Data primer adalah data yang diperoleh secara langsung dari lokasi penelitian, meliputi hasil pengumpulan data dan pengamatan secara langsung (observasi) pada saluran distribusi listrik primer di wilayah kota Palu, dan data hasil wawancara langsung dengan karyawan/pegawai PT. PLN (Persero) cabang Palu rayon kota.

2. Data sekunder dalam penelitian ini adalah data yang bersumber dari buku-buku, artikelartikel, dan jurnal-jurnal ilmiah yang memiliki hubungan dengan tujuan dan permasalahan penelitian.

\subsection{Tahapan Penelitian}

Penelitian ini dilakukan dengan melalui tahapan-tahapan sebagai berikut:

1. Melakukan pengamatan dan pengumpulan data saluran distribusi listrik primer pada PT. PLN (Persero) cabang Palu rayon kota.

2. Instalasi program (software) yang dibutuhkan serta pengaturannya.

3. Melakukan persiapan data yang telah ada sehingga dapat digunakan oleh program aplikasi. 
4. Merancang model saluran distribusi listrik primer sesuai dengan data yang diperoleh dari lokasi penelitian.

5. Melakukan pengetesan/pengujian dan menarik kesimpulan dari hasil pengetesan/pengujian tersebut.

\subsection{Perancangan Sistem dan Pemecahan Masalah Analisa Sistem}

Penelitian ini menggunakan program ArcView GIS 3.3 yang dilengkapi dengan pemrograman script Avenue. Tujuan penggunaan program ini adalah untuk memudahkan dalam melakukan penelitian tentang sistem informasi geografis dan kemudahan dalam mendapatkan informasi mengenai saluran distribusi listrik primer yang ada di wilayah kerja PT. PLN (Persero) cabang Palu rayon kota. Selain itu, dengan program ArcView GIS 3.3 yang dilengkapi dengan peta dan nama jalan di kota Palu yang sesuai dengan kondisi geografis maka akan memudahkan dalam melakukan desain saluran distribusi listrik primer yang baru.

\section{Diagram Aliran Data (Data Flow Diagram/DFD)}

Diagram aliran data merupakan model dari sistem untuk menggambarkan pembagian sistem ke modul yang lebih kecil (Ladjamudin, 2005:64). Salah satu keuntungan menggunakan diagram aliran data adalah memudahkan pengguna (user) yang kurang menguasai bidang komputer untuk mengerti sistem yang akan dikerjakan.

Diagram alir data (DAD) merupakan suatu model logika data atau proses yang dibuat untuk menggambarkan darimana asal data dan kemana tujuan data keluar dari sistem, dimana data disimpan, proses apa yang menghasilkan data tersebut dan interaksi antara data yang tersimpan dan proses yang dikenakan pada data tersebut (Kristanto, 2008:61).

DAD menggambarkan penyimpanan data dan proses yang mentransformasikan data. DAD menunjukkan hubungan antara data pada sistem dan proses pada sistem. DAD aplikasi sistem informasi geografis pada saluran distribusi listrik primer dapat digambarkan pada gambar 2.

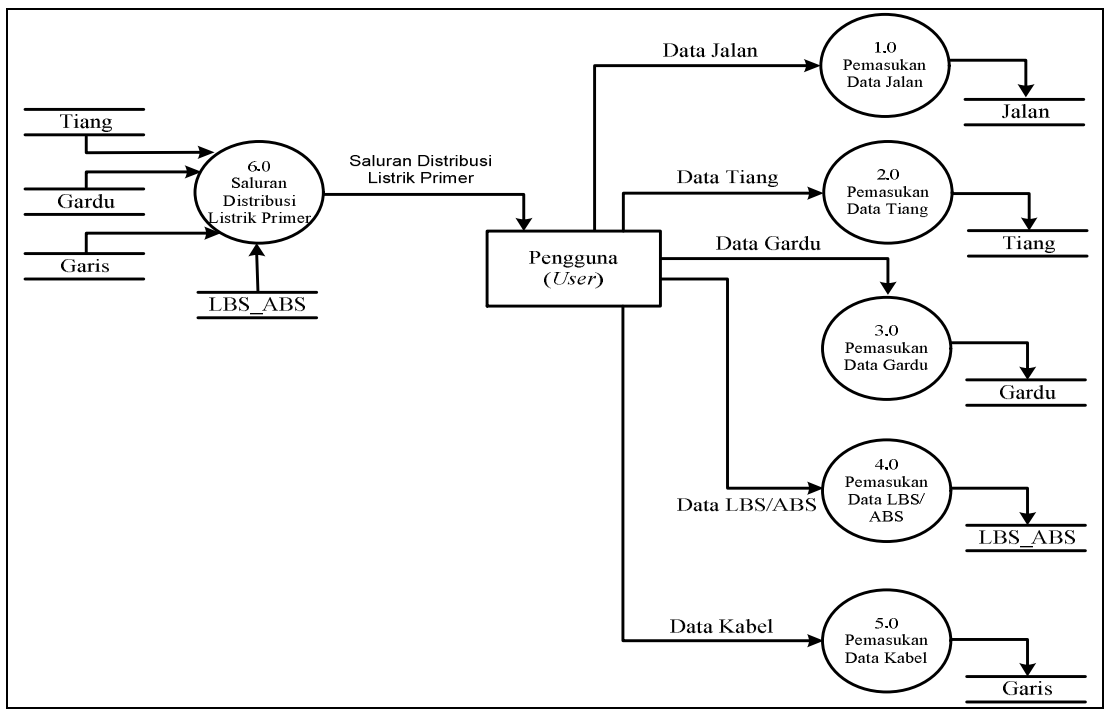

Gambar 2. Diagram alir data (DAD) level 1 aplikasi sistem informasi geografis pada saluran distribusi listrik primer

Gambar 2 di atas memperlihatkan diagram alir data (DAD) aplikasi sistem informasi geografis pada saluran distribusi listrik primer yang terdiri dari beberapa proses yaitu proses pemasukan data jalan, proses pemasukan data tiang, proses pemasukan data gardu, proses pemasukan data LBS/ABS, proses pemasukan data kabel, dan proses menampilkan saluran distribusi listrik primer.

\section{Perancangan Peta Digital Saluran Distribusi Listrik Primer}

Perancangan peta termasuk dalam bagian Sistem Informasi Geografis (Geographic Information System) yang merupakan suatu sistem berbasis komputer yang memberikan kemampuan dalam menangani data bereferensi geografis yang meliputi pemasukan, pengolahan 
atau manajemen data, manipulasi dan analisa data, serta keluaran. Data dalam sistem informasi geografis dibagi menjadi data spasial yang meliputi data raster (data image) dan data vektor (titik, garis, dan poligon), dan data non spasial (data atribut/tabel).

Peta yang digunakan dalam sistem ini merupakan jenis peta yang memiliki ketinggian permukaan bumi yang sama. Sedangkan jenis peta lainnya yaitu peta yang memperhatikan ketinggian permukaan bumi (peta topografi) dan peta yang menggunakan kontur (fisik pola permukaan bumi).

Perancangan peta saluran distribusi listrik primer diawali dengan melakukan digitasi terhadap peta yang berasal dari format gambar (image). Sebelum memasukkan data jalan, titiktitik tiang, gardu, dan LBS/ABS, serta data kabel saluran distribusi listrik, maka perlu memasukkan terlebih dahulu data geografis dari peta yang digunakan yaitu peta kota Palu, propinsi Sulawesi Tengah.

Langkah selanjutnya dalam perancangan ini adalah melakukan digitasi dengan memasukkan data spasial dan non spasial yang terdiri dari pemasukan data pada layar (theme) dan tabel jalan yang merupakan tipe garis (line), pemasukan data pada layar dan tabel tiang yang merupakan tipe titik (point), pemasukan data pada layar dan tabel kabel yang merupakan tipe garis, pemasukan data pada layar dan tabel gardu yang merupakan tipe titik, dan pemasukan data pada layar dan tabel LBS/ABS yang merupakan tipe titik. Setelah keseluruhan proses digitasi selesai, maka akan terbentuk secara lengkap peta saluran distribusi listrik primer di wilayah kota Palu yang akan digunakan dalam sistem informasi geografis.

\section{Perancangan Basis Data (Database)}

Program yang dibangun dengan ArcView GIS 3.3 menggunakan beberapa tabel basis data yaitu tabel Tiang, tabel Gardu, tabel LBS_ABS, tabel Kabel, tabel Garis, dan tabel Jalan. Relasi antar tabel-tabel tersebut diperlihatkan pada gambar 3.

\begin{tabular}{|c|c|c|}
\hline Gardu & Tiang & Garis \\
\hline \multirow{11}{*}{$\begin{array}{l}\text { Nama_gardu } \\
\text { Kode } \\
\text { Jns_gardu } \\
\text { Jml_fasa } \\
\text { Daya_kva } \\
\text { Teg_primer } \\
\text { Teg_sknder } \\
\text { Arus_pmr } \\
\text { Arus_skr } \\
\text { Beban_kva } \\
\text { Pelanggan } \\
\text { Mrk_gardu }\end{array}$} & \multirow{15}{*}{$\begin{array}{l}\text { Kd_tiang } \\
\text { Kode } \\
\text { Kd_jalan } \\
\text { Jns_tiang } \\
\text { Byk_tiang } \\
\text { Penyulang }\end{array}$} & \multirow{6}{*}{$\begin{array}{l}\text { Awal (Kd_tiang) } \\
\text { Akhir (Kd_tiang) } \\
\text { Kd_jalan } \\
\text { Kode_kabel } \\
\text { Jarak }\end{array}$} \\
\hline & & \\
\hline & & \\
\hline & & \\
\hline & & \\
\hline & & \\
\hline & & Kabel \\
\hline & & \multirow{3}{*}{$\begin{array}{l}\text { Kode_kabel } \\
\text { Jns_kabel }\end{array}$} \\
\hline & & \\
\hline & & \\
\hline & & Jalan \\
\hline LBS ABS & & \multirow{2}{*}{$\begin{array}{l}\text { Kd_jalan } \\
\text { Nama_jalan }\end{array}$} \\
\hline $\mathrm{Nm}$ lbs abs & & \\
\hline Kode & & \\
\hline Jn_lbs_abs & & \\
\hline
\end{tabular}

Gambar 3. Relasi antar tabel dalam aplikasi sistem informasi geografis pada saluran distribusi listrik primer

\section{HASIL DAN PEMBAHASAN}

Implementasi sistem informasi geografis pada saluran distribusi listrik primer dapat dijelaskan sebagai berikut:

1. Inisialisasi sistem (halaman awal)

Pada saat sistem mulai dijalankan, pertama kali sistem akan melakukan inisialisasi, yaitu:

a. Menampilkan peta kota Palu sebagai acuan dalam mendesain saluran distribusi listrik primer.

b. Menampilkan layar (theme) Jalan kota Palu yang semua datanya telah di simpan pada tabel Jalan.

c. Menampilkan layar Tiang distribusi listrik primer yang datanya telah disimpan pada tabel Tiang. 
d. Menampilkan layar Garis yang merupakan tampilan kabel saluran distribusi listrik primer yang menghubungkan antara titik-titik tiang distribusi. Data garis/kabel telah disimpan pada tabel Garis.

e. Menampilkan layar Gardu distribusi listrik primer dan datanya telah disimpan dalam tabel Gardu.

f. Menampilkan layar Lbs_abs yang merupakan tampilan dari titik-titik LBS (Load Breaker Switch) atau ABS (Air Breaker Switch) pada saluran distribusi listrik primer.

Tampilan halaman awal sistem ini diperlihatkan pada gambar 4.

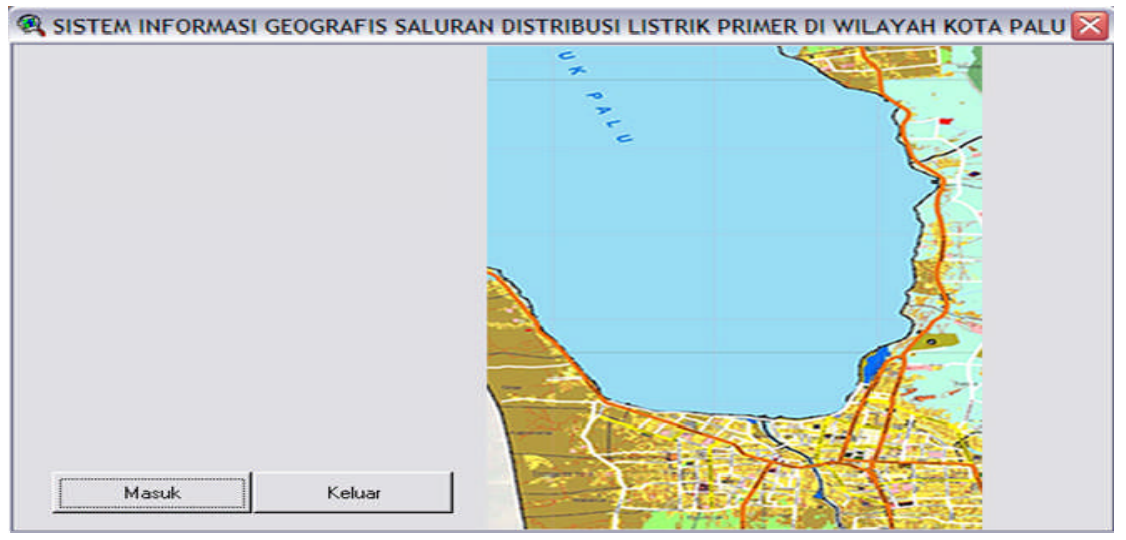

Gambar 4. Tampilan halaman awal masuk aplikasi sistem informasi geografis pada saluran distribusi listrik primer di wilayah kota Palu

2. Mendesain/memasukkan model saluran distribusi listrik primer sesuai dengan kondisi sebenarnya secara geografis dan memasukkan data jarak/panjang yang menghubungkan antara titik-titik tiang, gardu distribusi, dan LBS atau ABS. Langkah-langkah yang harus dilakukan adalah:

a. Meletakkan titik-titik tiang distribusi listrik primer pada layar Tiang. Tampilan proses pemasukkan titik-titik tiang distribusi dapat dilihat pada gambar 5 .

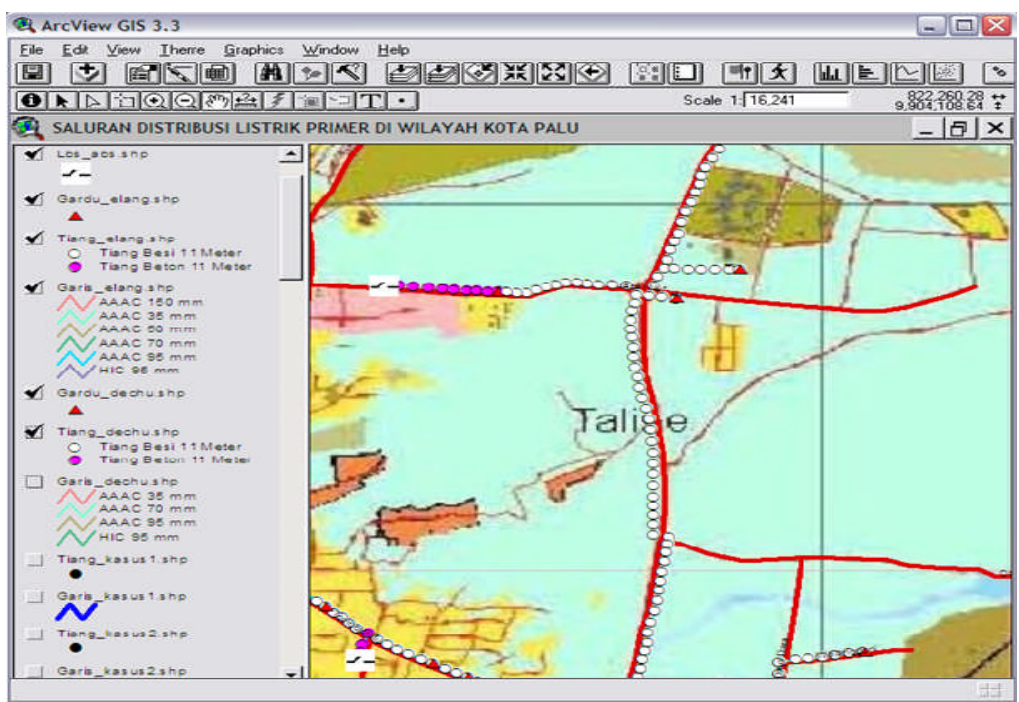

Gambar 5. Tampilan proses pemasukan titik-titik tiang saluran distribusi listrik primer di wilayah kota Palu

b. Pemasukkan data tiang pada tabel Tiang, agar dapat ditampilkan informasi mengenai tiang distribusi primer. Proses pemasukan data tiang pada tabel Tiang diperlihatkan pada gambar 6 . 


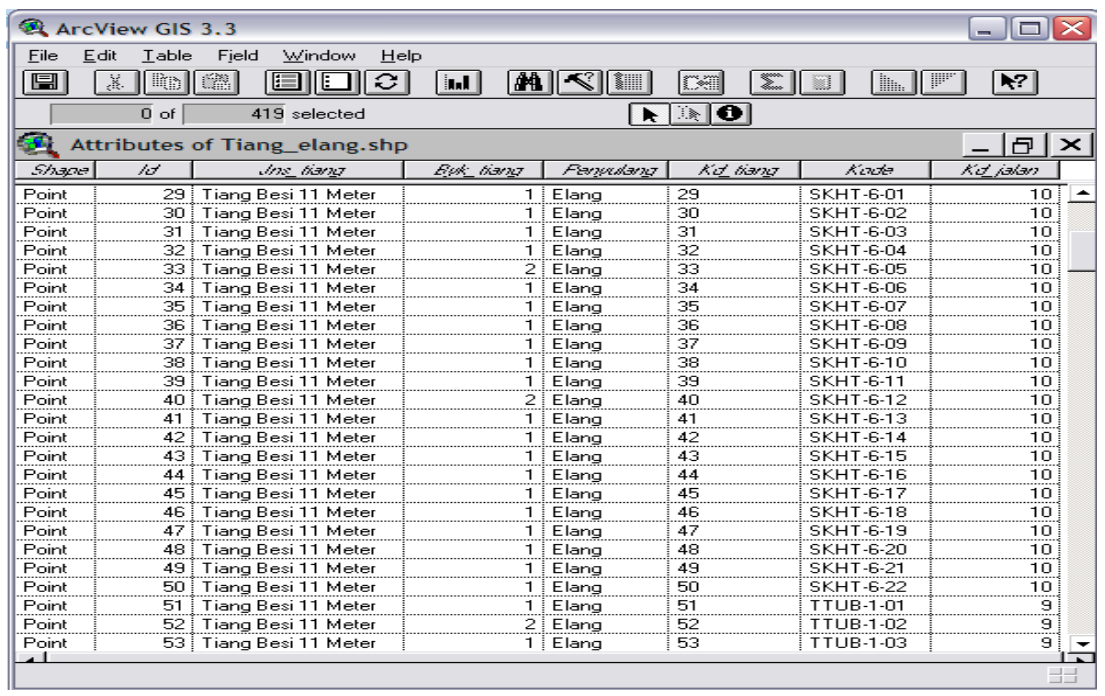

Gambar 6. Tampilan proses pemasukan data tiang pada tabel Tiang

c. Meletakkan titik-titik gardu distribusi pada layar Gardu dan titik-titik LBS/ABS pada layar Lbs_abs. Tampilan proses pemasukkan titik-titik gardu dan titik-titik LBS/ABS dapat dilihat pada gambar 7 .

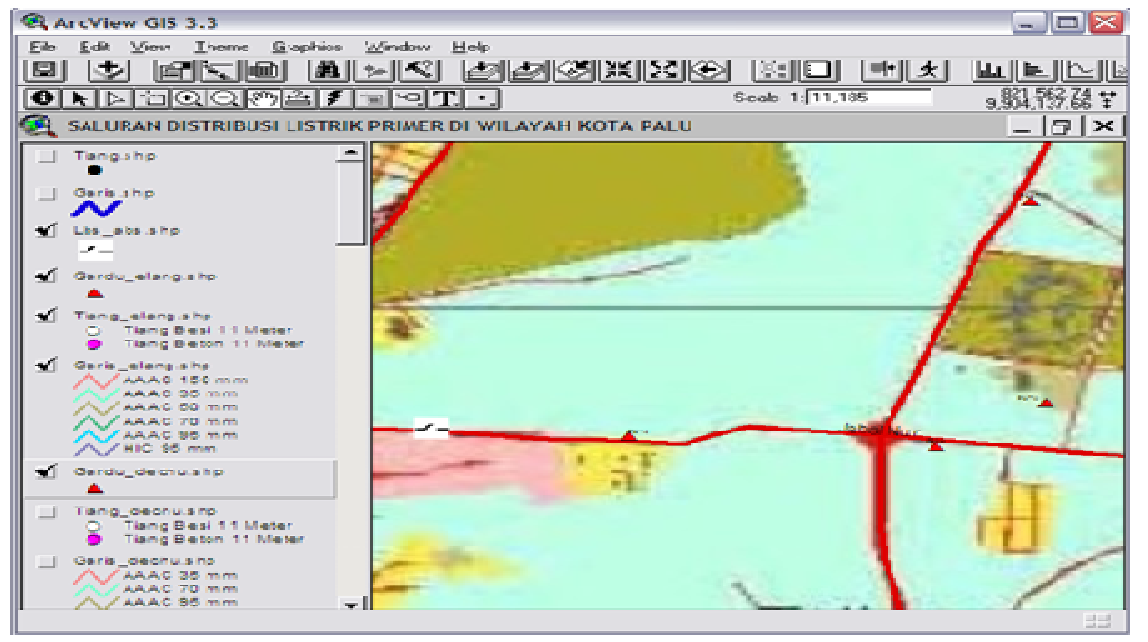

Gambar 7. Tampilan proses pemasukkan titik-titik gardu dan titik-titik LBS/ABS saluran distribusi listrik primer di wilayah kota Palu

d. Pemasukkan data gardu distribusi pada tabel Gardu dan data LBS atau ABS pada tabel Lbs_abs, agar dapat ditampilkan informasi mengenai gardu distribusi dan LBS/ABS. Proses pemasukan data gardu distribusi pada tabel Gardu dan data LBS/ABS pada tabel Lbs_abs diperlihatkan pada gambar 8. 


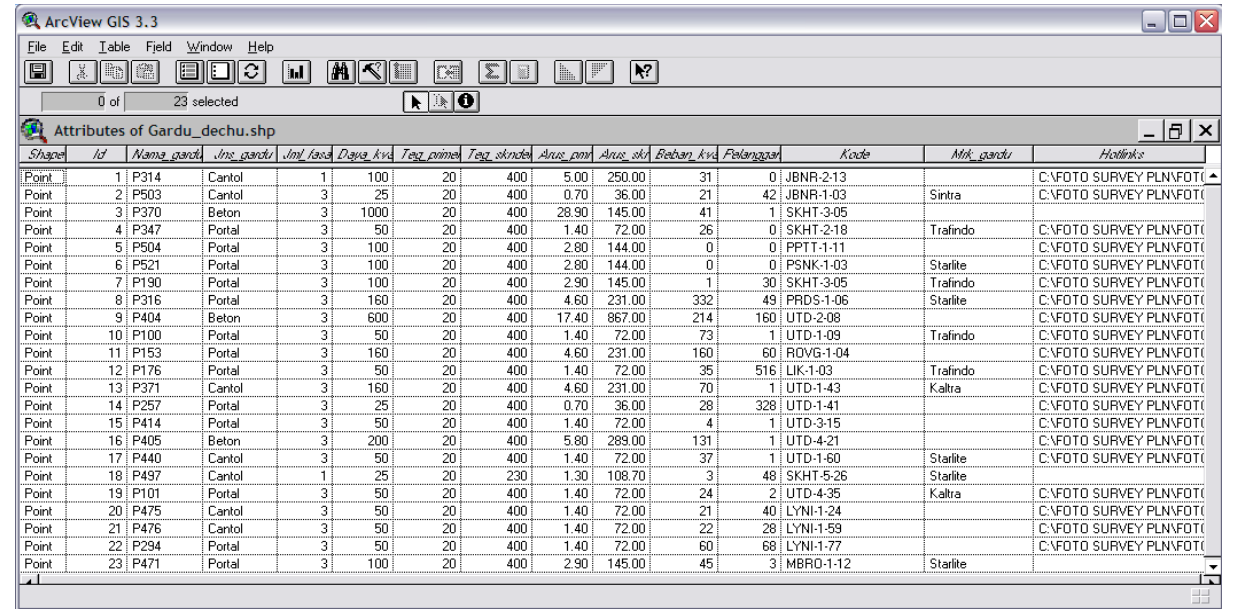

Gambar 8. Tampilan proses pemasukan data gardu distribusi pada tabel Gardu

e. Menghubungkan titik-titik tiang distribusi listrik primer dengan garis/kabel pada layar Garis. Tampilan hubungan garis pada layar Garis dapat dilihat pada gambar 9 .

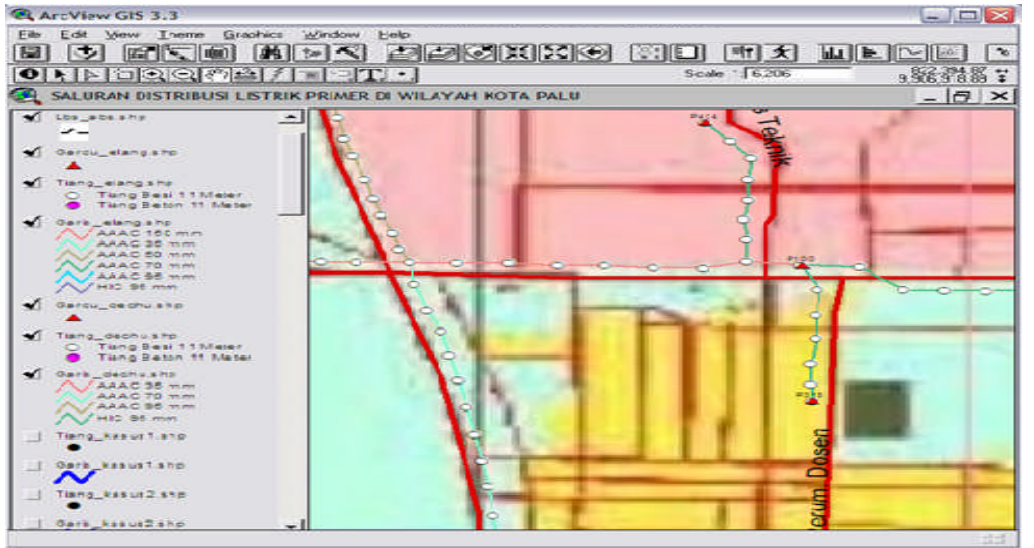

Gambar 9. Tampilan hubungan garis antara titik-titik tiang distribusi listrik primer di wilayah kota Palu

Kemampuan aplikasi sistem informasi geografis pada saluran distribusi listrik primer di wilayah kota Palu ini dapat dijelaskan sebagai berikut:

- Kemudahan dalam membuat sebuah peta digital. Peta digital yang digunakan pada sistem informasi geografis ini menggunakan sistem koordinat geografis yang akurat dan memiliki kemudahan dalam melakukan penyuntingan/pengeditan data misalnya untuk pemutakhiran data atau perubahan sistem koordinat.

- Kemudahan dalam pemasukan data tiang, gardu, dan LBS/ABS distribusi listrik primer.

- Pemrograman dengan menggunakan script Avenue dapat dilakukan dengan mudah.

- Mampu merelasikan tabel-tabel dalam basis data dengan mudah. Relasi antar tabel basis data dapat dilakukan dengan menggunakan fasilitas join dan link yang ada pada sistem, selain itu relasi antar tabel basis data dapat dilakukan melalui perintah-perintah yang ada dalam script Avenue. Dengan adanya relasi antar tabel terbukti dapat menciptakan sebuah basis data yang baik, efisiensi tempat penyimpanan data, integritas data yang tinggi, struktur masing-masing tabel yang lebih efisien dan sistematis, kecepatan pemrosesan, dan kemudahan dalam operasi basis data.

- Menampilkan peta saluran distribusi listrik primer berdasarkan kondisi geografis.

- Mampu mengolah data spasial dan non spasial.

- Menyediakan fasilitas pembesaran peta (zoom) dan penggeseran peta (pan).

- Menyediakan fasilitas hot link yang dapat menampilkan gambar/foto sebenarnya dari tiang, gardu, dan LBS/ABS distribusi listrik primer. 
- Kemudahan dalam peletakan titik-titik tiang, gardu, dan LBS/ABS.

- Kemudahan dalam menggambar/menghubungkan garis/kabel yang sesuai dengan kondisi geografis.

- Memberikan kebebasan pada pengguna untuk menampilkan layar peta mana yang akan ditampilkan.

- Kemudahan dalam mendesain saluran distribusi listrik primer yang baru.

- Menampilkan informasi secara keseluruhan saluran distribusi listrik primer yang ada di wilayah kota Palu.

\section{KESIMPULAN DAN SARAN}

\subsection{Kesimpulan}

Setelah dilakukan implementasi sistem informasi geografis pada saluran distribusi listrik primer di wilayah kota Palu, maka dapat diambil kesimpulan sebagai berikut:

1. Penelitian ini menggunakan program ArcView GIS 3.3 yang dilengkapi dengan pemrograman script Avenue untuk mengimplementasikan sistem informasi geografis saluran distribusi listrik primer di wilayah kota Palu dengan menggunakan peta digital dan relasi antar tabel basis data.

2. Sistem informasi geografis yang dirancang dan dibuat pada penelitian ini terbukti mampu menampilkan keseluruhan informasi yang ada pada saluran distribusi listrik primer dimana datanya diambil dari PT. PLN (Persero) cabang Palu rayon kota. Informasi yang dapat ditampilkan antara lain informasi tiang-tiang distribusi, gardu distribusi, LBS/ABS, $\mathrm{kabel} /$ penghantar yang digunakan, dan lain-lain.

3. Peta digital yang digunakan pada sistem informasi geografis ini sangat mudah untuk dibuat, menggunakan sistem koordinat geografis yang akurat, dan memiliki kemudahan dalam melakukan penyuntingan/pengeditan data misalnya untuk pemutakhiran data atau perubahan sistem koordinat.

4. Relasi antar tabel dalam basis data terbukti dapat menciptakan sebuah basis data yang baik, efisiensi tempat penyimpanan data, integritas data yang tinggi, struktur masing-masing tabel yang lebih efisien dan sistematis, kecepatan pemrosesan, dan kemudahan dalam operasi basis data.

\subsection{Saran}

Saran yang dapat diberikan dalam penelitian ini adalah sebagai berikut:

1. Data saluran distribusi listrik primer pada sistem informasi geografis yang dibuat pada penelitian ini sebaiknya selalu diperbarui agar tetap menghasilkan informasi yang akurat.

2. Peta digital yang digunakan sebagai dasar desain saluran distribusi listrik primer dapat ditambahkan dengan menggunakan peta yang sesuai dengan topografi suatu wilayah. 


\section{DAFTAR PUSTAKA}

Fathansyah, (1999), Basis Data, Informatika, Bandung.

Hage, (2008), Dunia Listrik: Sistem Distribusi Tenaga Listrik, http://dunialistrik.blogspot.com/2008/12/sistem-distribusi-tenaga-listrik.html, diakses [13 Agustus 2012].

Kadir, A., (2003), Pengenalan Sistem Informasi, Andi, Yogyakarta.

Kadir, A., (2006), Distribusi dan Utilisasi Tenaga Listrik, Universitas Indonesia Press, Jakarta.

Kristanto, A., (2008), Perancangan Sistem Informasi dan Aplikasinya, Gava Media, Yogyakarta.

Ladjamudin, A. B., (2005), Analisis dan Desain Sistem Informasi, Graha ilmu, Yogyakarta.

Marsudi, D., (2006), Operasi Sistem Tenaga Listrik, Graha Ilmu, Yogyakarta.

Nuryadin, R., (2005), Panduan Menggunakan Mapserver, Informatika, Bandung.

Oetomo, B. S. D., (2006), Perencanaan dan Pembangunan Sistem Informasi, Andi, Yogyakarta.

Prahasta, E., (2004), Sistem Informasi Geografis: ArcView Lanjut Pemrograman Bahasa Script Avenue, Informatika, Bandung.

Prahasta, E., (2009), Sistem Informasi Geografis: Tutorial ArcView, Informatika, Bandung.

Yousman Y., (2004), Sistem Informasi Geografis dengan Maplnfo Professional, Andi, Yogyakarta. 